\title{
Acupuncture treatment for a dog with allergy - a case report
}

\author{
Alena Michál'ová1*, Mária Fialkovičová1, and Zoran Vrbanac ${ }^{2}$ \\ ${ }^{1}$ Department of Internal Diseases, Small Animal Clinic, University of Veterinary Medicine and Pharmacy in Košice, \\ Košice, Slovakia \\ ${ }^{2}$ Department of Radiology, Ultrasound Diagnostic and Physical Therapy, Faculty of Veterinary Medicine, University \\ of Zagreb, Zagreb, Croatia
}

MICHÁLOVÁ, A., M. FIALKOVIČOVÁ, Z. VRBANAC: Acupuncture treatment for a dog with allergy - a case report. Vet. arhiv 91, 101-108, 2021.

\section{ABSTRACT}

Allergies are a malfunction of the immune system that causes a reaction to normally harmless substances known as allergens, such as food components, pollen, insects, or medication. Due to the extensive incidence of clinical signs, it is very important to make a correct diagnosis to eliminate the offending allergen from the body, to provide control and long term management to achieve a comfortable life for the animal. In the case of highly intensive pruritus, drugs such as glucocorticoids, antihistamines and inhibitors of Janus kinase are generally administered. Unfortunately common drugs are not always able to resolve the problem. This case report describes the use of alternative treatments, including veterinary acupuncture, diet and phytotherapy that showed a beneficial and curative effect in a case of allergies.

Key words: allergy; traditional Chinese veterinary medicine; acupuncture; diet; phytotherapy

\section{Introduction}

Allergies in dogs are constantly increasing and they are one of the most common causes of dermatological, respiratory and gastrointestinal problems in small animals (STEINER, 2008). Nowadays, many dogs are allergic to pollens, grasses, mites, or food components, or they have cross-reactivity between aeroallergens and food allergens. Pollen is a typical cause of seasonal allergies. In the case of seasonal allergies most pollens that cause allergic reactions come from trees, weeds and grasses. These plants create small, light and dry pollen grains that travel on the wind. In many allergic reactions the immune system produces a type of antibody that reacts

to the antigen (mites, pollen, food components). Immunoglobulin E (IgE) antibodies bind to basophils in the bloodstream and to mast cells in the tissues (MUELLER and UNTERER, 2018). The first exposure makes an animal sensitive to the allergen, but does not cause any symptoms. If an animal has been already sensitized by an allergen, the basophils and mast cells with IgE on their surface release substances such as histamine, prostaglandins, and leukotrienes, that cause swelling or inflammation in the surrounding tissues. Progressively, these substances activate a cascade of reactions that continue to irritate and damage tissues, with mild to severe reactions (SVOBODA

\footnotetext{
*Corresponding author:

Dr. Alena Michál'ová, University of Veterinary Medicine and Pharmacy, Komenského 73, Košice, Slovakia, E-mail: ale.michalova@gmail.com
} 
et al., 1994). Feed-based hypersensitivity, unlike food intolerance (food poisoning, food idiosyncrasy, anaphylactic, metabolic and pharmacological reactions), is based on immunological responses to the antigen received in the feed (MUELLER and JACKSON, 2003). Although food intolerance and food allergy manifest equally, their differentiation based on clinical signs is very difficult.

The clinical symptoms of a hypersensitive reaction include watery and itchy eyes, running nose, itchy skin, and sneezing. Pruritus, that affects the ears, feet, inguinal parts, the axillary area, face, neck and perineum, is also present. In addition to pruritus, erythema, papules, alopecia, crusts and hyperpigmentation may occur. Affected individuals are prone to secondary bacterial infections, such as Malassezia dermatitis. In some patients, otitis externa is the only manifesting symptom (MUELLER and UNTERER, 2018; STEINER, 2008). Gastrointestinal symptoms occur in 20$30 \%$ of patients, and include vomiting, diarrhea, weight loss, abdominal pain, borborygms and flatulence (PICCO et al., 2008; PROVERBIO et al., 2010; JOHANSEN et al., 2017; VOLKMANN et al., 2017). Approximately $20-30 \%$ of dogs with a food allergy suffer from other allergies such as hypersensitivity to flea bites or atopic dermatitis (ROUDEBUSH, 2013).

Diagnosis may be provided by blood tests, a skin prick test, an allergen-specific serum IgE test or an elimination diet. Blood tests may detect a higher presence of eosinophils if an allergic reaction has occurred. The skin prick test uses dilute solutions made from extracts of pollens, fungal spores, dust mites, animal dander, insect venom, foods and some drugs. Another test is the allergen-specific serum IgE test that is a blood test applied when skin tests cannot be used. An elimination diet is also one of the diagnostic methods. It is followed by exposure to the suspected allergen. The diet consists of feeding at least 8 to 12 weeks of feed, which the individual has not yet received. These are either commercial diets with selected proteins, diets prepared at home, or commercial diets containing hydrolyzed proteins.
According to conventional medicine, allergies are usually treated symptomatically by systemic and local medicaments. Allergen exclusion is usually very complicated and, in veterinary practice, it is recommended to proceed with an elimination diet, use of inhibitors of Janus kinase, corticoids or antihistamines (LUCKSCHANDER et al., 2006; ROSTAHER et al., 2017). There are also some alternative types of treatment, such as acupuncture and phytotherapy, which could be curative and helpful in a case of allergy (SCHOEN, 2001). Traditional Chinese Medicine (TCM) uses principles and theories as its foundation in health assessment for determination of the best form of treatment (SWATI et al., 2011). Acupuncture, one of the components of TCM, was introduced about 3000 years ago (RUŽIČKA, 1990). The approach to treatment is very individual for each animal. Signs and symptoms are evaluated, and a syndrome analysis is created, after the collection of all available information about the animal's health status according to TCM principles. The treatment is geared towards the causative factors, not just symptoms.

\section{Case presentation}

A five-year-old female Dogue de Bordeaux was presented with signs of a runny nose (Fig.1), dry skin on the face and planum nasale, irritated eyes (Fig.2), hair loss, and itchy skin changes on the right forelimb and abdominal areas (Fig. 3). Upon admission, she was listless. Initially, symptoms mainly appeared during the spring and summer, but later throughout the whole year. The animal was particularly sensitive to environmental aeroallergens. The history revealed that Prednisone in a dose of $10 \mathrm{mg}$ twice per day had been administered to the patient for a long time. A food allergy blood test was performed and confirmed soy and veal allergies. After unsuccessful pharmacological treatment, the owners decided to try an alternative therapy. 


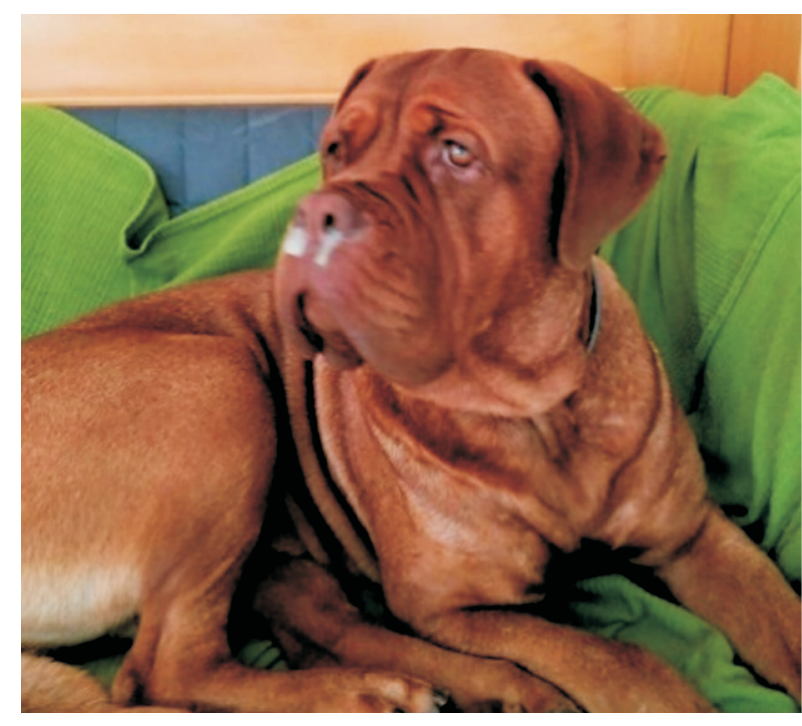

Fig.1. Symptoms of allergy in the dog - the presence of nasal discharge

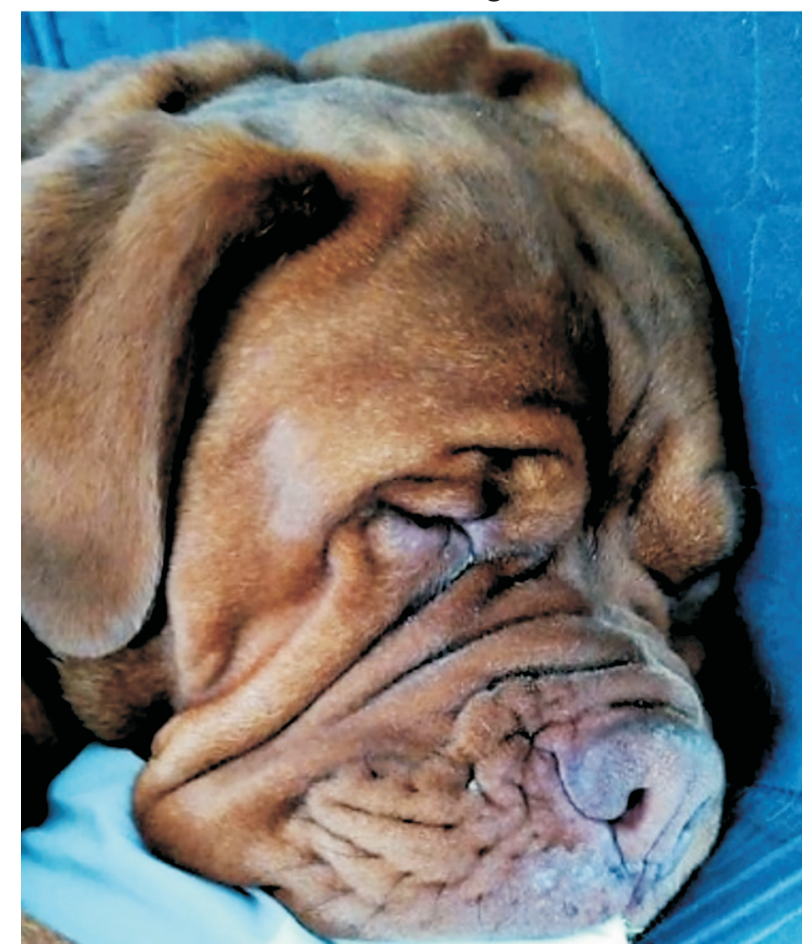

Fig. 2. The dog is listless, there is dry skin on the face and planum nasale

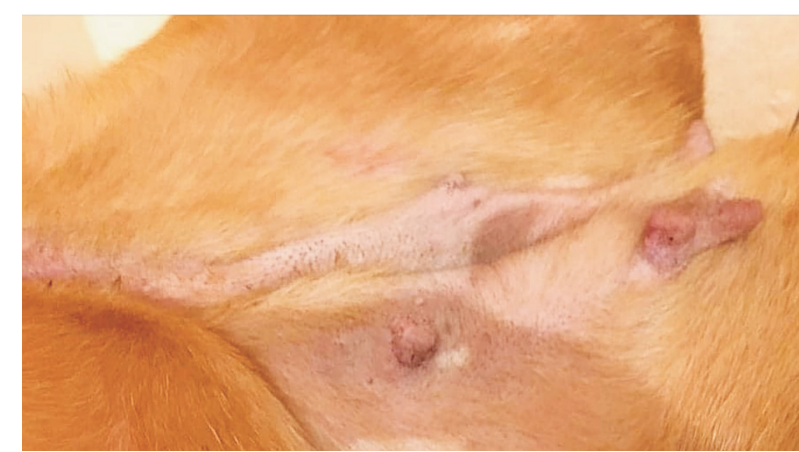

Fig. 3. Hair loss and itchy skin on the dog's abdominal area

\section{Clinical examination}

All vital signs were within the physiological range. The tongue was pale and dry. The skin was dry with pruritic exanthema and red spots on the abdominal area and on the right forelimb. After the skin scraping test, the presence of ectoparasites and molds was excluded. Haematological examination showed eosinophilia (Table 1), although the dog had been regularly dewormed. Other blood parameters were within the range of the physiological values.

Table 1. Patient's haematological parameters determined by LaserCyte Dx (IDEXX)

\begin{tabular}{|l|c|c|}
\hline Test & Results & Reference values \\
\hline RBC & $5.53 \mathrm{~m} / \mu \mathrm{L}$ & $5.50-8.50$ \\
\hline HCT & $38.2 \%$ & $37.0-55.0$ \\
\hline HBG & $13.6 \mathrm{~g} / \mathrm{dL}$ & $12.0-18.0$ \\
\hline MCV & $69.1 \mathrm{fL}$ & $60.0-77.0$ \\
\hline MCH & $24.6 \mathrm{pg}$ & $18.5-30.0$ \\
\hline MCHC & $35.6 \mathrm{~g} / \mathrm{dL}$ & $30.0-97.5$ \\
\hline RDW & $15.4 \%$ & $14.7-17.9$ \\
\hline RETIC & $34.5 \mathrm{~K} / \mu \mathrm{L}$ & $10.0-110.0$ \\
\hline WBC & $15.46 \mathrm{~K} / \mu \mathrm{L}$ & $5.50-16.90$ \\
\hline NEU & $9.55 \mathrm{~K} / \mu \mathrm{L}$ & $2.00-12.00$ \\
\hline LYM & $2.65 \mathrm{~K} / \mu \mathrm{L}$ & $0.50-4.90$ \\
\hline MONO & $1.32 \mathrm{~K} / \mu \mathrm{L}$ & $0.30-2.00$ \\
\hline EOS & $1.92 \mathrm{~K} / \mu \mathrm{L} \uparrow$ & $0.10-1.49$ \\
\hline BASO & $0.02 \mathrm{~K} / \mu \mathrm{L}$ & $0.00-0.10$ \\
\hline PLT & $268 \mathrm{~K} / \mu \mathrm{L}$ & $175-500$ \\
\hline
\end{tabular}




\section{Therapy}

After clinical examination and presumed diagnosis, we decided to apply acupuncture therapy. In all the sessions we used special combinations of acupuncture points.
These points are presented in the table (Table 2), where the location and indication of individual points are explained.

Table 2. Location and indication of acupuncture points applied during therapies

\begin{tabular}{|c|c|c|}
\hline $\begin{array}{l}\text { Acupuncture } \\
\text { point }\end{array}$ & Location & Indication \\
\hline BL-12 & $\begin{array}{l}\text { At the level of the lower border of the spinous } \\
\text { process of the second thoracic vertebra. }\end{array}$ & Nasal discharges, cough, common cold. \\
\hline BL -13 & $\begin{array}{l}\text { The point is approximately midway between } \\
\text { the midsagittal plane and the medial border of } \\
\text { scapula. }\end{array}$ & Asthma, bronchitis, pneumonia. \\
\hline BL- 18 & $\begin{array}{l}\text { Lateral to the caudal border of the spinous } \\
\text { process of the tenth thoracic vertebra. }\end{array}$ & Conjunctivitis, liver and gallbladder problems. \\
\hline BL- 23 & $\begin{array}{l}\text { Lateral to the caudal border of the spinous } \\
\text { process of the second lumbar vertebra, along } \\
\text { the longitudinal line of the thoracic costal } \\
\text { tubercula. }\end{array}$ & Allergic attacks, asthma, rhinitis. \\
\hline BL-40 & $\begin{array}{l}\text { Back of the knee, on the popliteal crease, in a } \\
\text { depression midway between the tendons of the } \\
\text { biceps femoris and semitendinosus. }\end{array}$ & $\begin{array}{l}\text { Hemiplegia, abdominal pain, vomiting, } \\
\text { diarrhea. }\end{array}$ \\
\hline LI- 4 & $\begin{array}{l}\text { Between the first and second metacarpal } \\
\text { bones, at the level of the end of the first } \\
\text { metacarpus. }\end{array}$ & $\begin{array}{l}\text { Skin disorders, acupuncture analgesia, } \\
\text { neurodermatitis. }\end{array}$ \\
\hline LI -11 & $\begin{array}{l}\text { At the lateral end of the cubital fossa when the } \\
\text { elbow joint is flexed at a right angle. }\end{array}$ & $\begin{array}{l}\text { Neurodermatitis, skin disorders, Homeostatic } \\
\text { and immune enhancing point. Often used in } \\
\text { allergic and infectious disorders. }\end{array}$ \\
\hline LIV -3 & $\begin{array}{l}\text { On the dorsum of the foot, in the depression } \\
\text { proximal to the first metatarsal space. }\end{array}$ & $\begin{array}{l}\text { Gastrointestinal and urogenital problems, } \\
\text { distal point for eye disorders. }\end{array}$ \\
\hline $\mathrm{LU}-7$ & $\begin{array}{l}\text { On the radial margin of the forearm, superior } \\
\text { to the styloid process of the radius. }\end{array}$ & $\begin{array}{l}\text { Neck rigidity, facial paralysis, toothache, sore } \\
\text { throat, cough, asthma, nasal problems. }\end{array}$ \\
\hline LU- 9 & $\begin{array}{l}\text { On the palm-side of the wrist, in the } \\
\text { depression beneath the thumb, between the } \\
\text { point where you can feel your pulse and the } \\
\text { tendon that goes to your thumb. }\end{array}$ & $\begin{array}{l}\text { Respiratory disorders, moistens skin, and for } \\
\text { cough and asthma. }\end{array}$ \\
\hline
\end{tabular}

In the first session, we used the following points: BL13-18-23, LI-4, LU-7, LIV-3. Every session lasted twenty minutes. The next session was two weeks later when the owners stated that the dog was still scratching. We recommended that the patient's regular diet should be gradually changed to BARF (Biologically Appropriate Raw Food). As feed conversion had to be gradual, the animal was first fed a combined diet $(50 \%$ of the feed consisted of commercial feed and $50 \%$ of a natural feed) and after ten days the feed was completely converted to a raw diet. At the second session, we applied the following acupuncture points to the patient: LI11, LI-4, BL-40, LIV-3, BL-18, and LU9. We changed some points according to the animal's 
condition, because of the presence of pruritus that is caused by wind, heat and damp according to TCM. We used other points to eliminate it. So we added points at LI 11 for elimination of Wioth cases, sive incidencemally f pruritus, skin reparation, tonification of organs associated to skin problems. ind and pruritus, BL 40 to clear Heat and refresh (recover) Blood, LU9 for tonification of the Lungs. All points were used for tonification (promoting the function) of the lungs, elimination of pruritus, skin reparation, and tonification of organs associated with skin problems. The acupuncture treatment was performed once every fourteen days. In the next session we recorded a reduction in pruritus in the patient and improvement of the skin lesions, but otitis appeared. In the third and fourth sessions we used the following points: LI-11, LU-9, BL-12-13-18, LIV-3. After two weeks, according to the animal's status we chose acupuncture therapy using these points: LI 4-11, LU-9, BL12-13-18-40, LIV-3. The animal still had otitis, pruritus and two pustules on the abdomen. After other two weeks we applied the last acupuncture therapy to the patient. Its skin condition had been greatly modified, the otitis, lesions and pruritus had completely disappeared, but the animal was showing moderate aggression towards other dogs, so for the final session we chose the following points as acupuncture therapy: LI 4-11, LU-9, BL-12-18, LIV-3, and we recommended to the owners to use a nutritional supplement containing Silybum marianum for a period of one month to promote the function of the Liver and completely clean - detoxify the organism and calm the animal. After this therapy (Fig. 4), the condition of the animal had completely improved, and the symptoms as well as the signs of aggression towards the other dogs had disappeared.

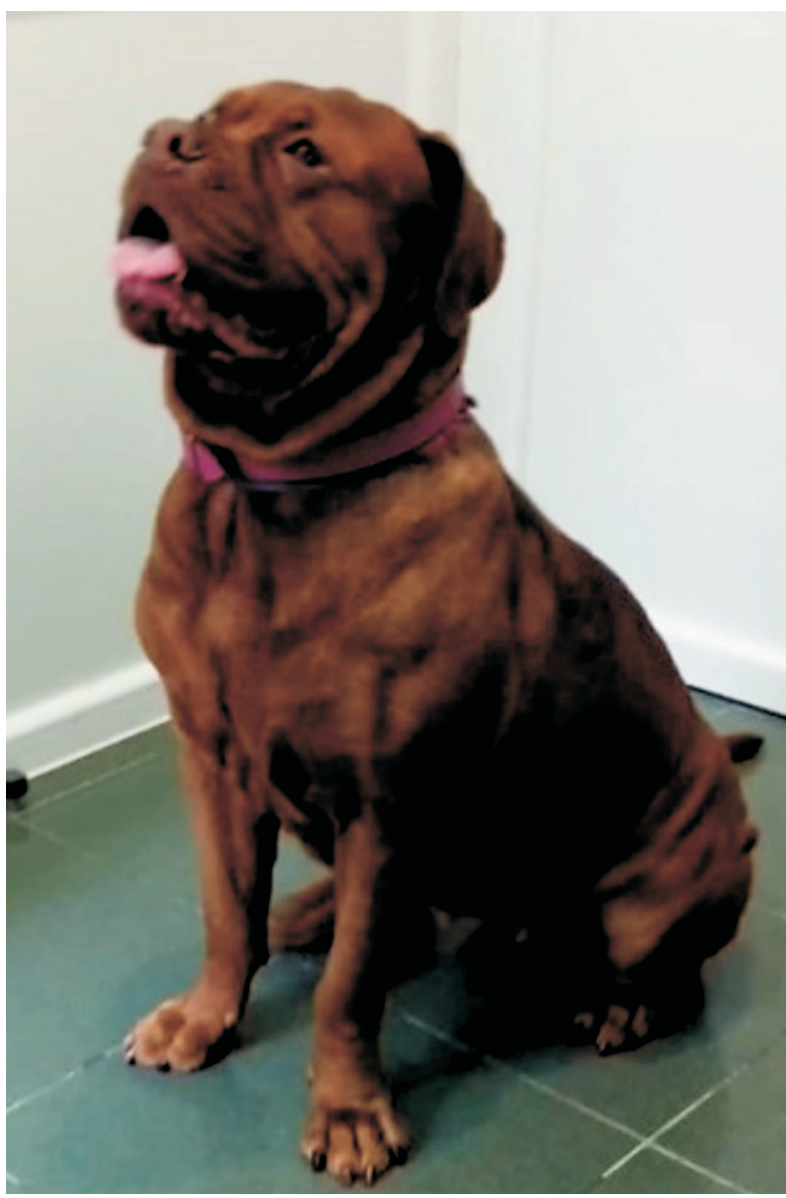

Fig. 4. The dog after acupuncture and phytotherapy

\section{Discussion}

In veterinary practice there are many cases of allergy in dogs, which may be the result of an allergic reaction to pollen, mites, food components such as proteins, or some additive or toxic substances. In all cases a cross-type allergic reaction to food and allergens from the environment also occurs. In our case report, because no improvement occurred after corticosteroid therapy, we decided to stabilize the patient's condition using the long-established traditional methods of TCM, especially acupuncture, diet and phytotherapy. If we want to achieve successful results it is necessary use all these three factors together because they complement each other. 
Diet is one of the most important preventive and therapeutic methods used in alternative medicine. However, if the diet is applied independently as a treatment of an allergy, at least one to three months are needed to see the final effect, so it is more effective to combine diet with acupuncture and phytotherapy. Raw diets are most suitable for animals, because their digestive system is able to handle raw food, and many chronic digestive issues disappear when the diet is changed correctly (BUFFINGTON et al., 2004). According to TCM, appetite changes are an important way to balance energy, and for comfort and health. In China there is food used for treating illness and it is classified by its energetic qualities (WEIDINGER, 2015). As traditional Chinese medicine focuses on each individual independently, we have to consider the patient's energy and health status during each appointment (MA et al., 2005). Therefore, we did not always use exactly the same acupuncture points for individual therapies. We mentioned above that the animal was showing moderate aggression towards other dogs. For this reason we chose a phytotherapic agent containing silimarin as a supplement. Silimarin has a detoxifying, soothing and antipruritic effect (WYNN and FOUGER, 2007). According to TCM, the liver belongs to the element Wood. The characteristic emotional expression of this element is aggression and anger. According to TCM pruritus, is bound to the Liver. The Liver works as a "filter" so if the conditions are significantly pruritic it is good to remove toxic substances from the Liver by using Silimarin to gradually eliminate the "Wind " accumulated in the liver, that is, one of the pathogenic factors affecting the patient's medical condition (XIE and PREAST, 2013).

There are many studies investigating the efficacy of acupuncture in allergies. The antipruritic effects of acupuncture have been demonstrated with artificially-induced pruritus in healthy patients in placebocontrolled studies (NAPADOW et al., 2014). Acupuncture has shown better results than antihistamines and preventive antipruritic systemic drugs (NAPADOW et al., 2014; IKOMA et al., 2006). A pilot study showed that in allergic patients, acupuncture provided a reduction in basophils activation (PFAB et al., 2011). Another study showed that acupuncture reduced serum IgE levels, as well as mRNA expressions of IL-4, IL-8, and TNF- $\alpha$ proinflammatory cytokines (PARK et al., 2013). Acupuncture has a modulatory effect on cytokines, hormones, neurotransmitters, growth factors, and oxidative factors (VAN DEN BERG-WOLF and BURGOON, 2017). The mechanism of the antipruritic effects of acupuncture in the brain has been studied by functional Magnetic Resonance Imaging (NAPADOW et al., 2014). Some researchers have reported a decrease in the itch-evoked activation in the putamen, insula, the premotor cortex, and the prefrontal cortex of the brain, as well as a reduction in the sensation of pruritus (IKOMA et al., 2004). Acupuncture treatment can be effective in modulation of central sensitization and is effective in stress reduction and treatment of emotional disturbances. It has also been used in the treatment of anxiety and depression disorders (ASHER et al., 2017). Acupuncture affects the limbic system, which is responsible for stressrelated symptoms, so stress can be responsible for recurrences of allergy and pruritic status (HUI et. al., 2010). In the studies the point LI-11 was used in pruritic patients as a basic antipruritic point, and through stimulation of this point with needling, pressure or moxa the pruritic sensation in patients was reduced (PARK et al., 2013; TSAI et al., 2014). LI -11 is an important point of the Large Intestine channel, which according to TCM can eliminate the Yang pathogen called Heat 
that causes itchy, dry, and scaly inflamed skin conditions and skin problems. This acupuncture point can be used in these skin conditions, and it is also able to reduce mRNA expression of pro-inflammatory cytokines and proteins (NAPADOW et al., 2014). All these aspects underline the fact that acupuncture, by improving the symptoms of atopic dermatitis and prolonging the time between flare-ups with a lower risk of side effects, could be a promising therapy for patients with allergies.

\section{Conclusion}

In accordance with a large amount of research, we can confirm that traditional therapeutic methods, such as acupuncture, diet and phytotherapy, were also very beneficial in the present case of allergies in a dog. If these non-invasive methods are correctly administered, they are able to improve symptoms such as pruritus, and dry, inflamed skin conditions, and they can also reduce stress without any known side effects that would be harmful for the organism. The number of therapeutic sessions for each animal is individual and depends on its health and psychological status. According to TCM, these traditional treatments can be also successful therapeutic methods in veterinary practice.

\section{References}

ASHER, G. N., J. GERKIN, B. N. GAYNES (2017): Complementary therapies for mental health disorders. Med Clin. North Am. 101, 847-864.

DOI: $10.1016 /$ j.mcna.2017.04.004

BUFFINGTON, T., C. H. HOLLOWAY, S. ABOOD (2004): Manual of Veterinary Dietetics. ${ }^{\text {st }}$. ed., Saunders Elsevier, St. Louis, USA, pp. 143-147.

HUI, K. K., O. MARINA, J. LIU, B. R. ROSEN, K. K. KWONG (2010): Acupuncture, the limbic system, and the anticorrelated networks of the brain. Autonomic Neuroscience 157, 81-90

DOI:10.1016/j.autneu.2010.03.022

IKOMA, A., M. FARTASCH, G. HEYER, Y. MIYACHI, H. HANDWERKER, M. SCHMELZ (2004): Painful stimuli evoke itch in patients with chronic pruritus: Central sensation for itch. Neurology 62, 212-217.

DOI: 10.1212/WNL.62.2.212
IKOMA, A., M. STEINHOFF, S. STÄNDER, G. YOSIPOVITCH, M. SCHMELZ, (2006): The neurobiology of itch. Nat. Rev. Neurosci. 7, 535-547.

DOI:10.1038/nrn1950

JOHANSEN, C., C. MARIANI, R. S. MUELLER (2017): Evaluation of canine adverse food reaction by patch testing with single proteins, single carbohydrates and commercial foods. Vet. Dermatol. 28, 473-109.

DOI:10.1111/vde. 12455

LUCKSCHANDER, N., K. ALLENSPACH, J. HALL, F. SEIBOLD, A. GRÖNE, M. G. DOHERR, F. GASCHEN (2006): Perinuclear antineutrophilic cytoplasmic antibody and response to treatment in diarrheic dogs with food responsive disease or inflammatory bowel disease. J.of Vet. Int. Medi. 20, 221-227.

DOI:10.1892/0891-6640(2006)20[221:pacaar]2.0.co;2

MA, Y., M. MA, Z. H. CHO (2005): Biomedical Acupuncture for Pain Management: An Integrative Approach. $1^{\text {st }}$ ed., Elsevier, St. Louis, USA, p. 90

MUELLER, R. S., H. JACKSON (2003): Atopic dermatitis and food adverse reaction. Manual of Small Animal Dermatology. $2^{\text {nd }}$ ed., British Small Animal Veterinary Association, Gloucester, England, UK, pp. 125-136.

MUELLER, R. S., S. UNTERER (2018): Adverse food reactions: Pathogenesis, clinical signs, diagnosis and alternatives to elimination diets. Vet. J. 236, 89-85.

DOI:10.1016/j.tvj1.2018.04.014

NAPADOW, V., A. LI, M. L. LOGGIA, J. KIM, P. C. SCHALOCKE, LERNER, T. N. TRAN, J. RING, B. R. ROSEN, T. J. KAPTCHUK, F. PFAB (2014): The brain circuitry mediating antipruritic effects of acupuncture. Cereb Cortex 24, 873-882.

DOI:10.1093/cercor/bhs363

PARK, J. Y., H. J. PARK, Y. Y. CHOI, M. H. KIM, S. N. KIM, W. M. YANG (2013): Effects of acupuncture on 1-chloro2,4-dinitrochlorobenzen-induced atopic dermatitis. Evid. Based Complement Alternat. Med., ID 982095.

DOI:10.1155/2013/982095

PFAB, F., G. I. ATHANASIADIS, G. I., J. HUSS-MARP, J. FUQIN, B. HEUSER, L. CIFUENTES, K. BROCKOW, W. SCHOBER, A. KONSTANTINOW, D. IRNICH, H. BEHRENDT, J. RING, M. OLLERT (2011): Effect of acupuncture on allergen-induced basophil activation in patients with atopic eczema: A pilot trial. J. Altern. Complement. Med. 17, 309-314.

DOI:10.1089/acm.2009.0684

PICCO, F., E. ZINI, C. NETT, C. NAEGELI, B. BIGLER, S. RÜFENACHT, P. ROOSJE, M. E. RICKLIN GUTZWILLER, S. WILHELM, J. PFISTER, E. MENG, C. FAVROT (2008): A prospective study on canine atopic dermatitis and food-induced allergic dermatitis in Switzerland. Vet. Dermatol. 19, 150-155.

DOI:10.1111/j.1365-3164.2008.00669.x 
PROVERBIO, D., R. PEREGO, E. SPADA, E. FERRO (2010): Prevalence of adverse food reactions in $130 \mathrm{dogs}$ in Italy with dermatological signs: A retrospective study. J. Small Anim. Pract. 51, 370-374.

DOI:10.1111/j.1748-5827.2010.00951.x

ROSTAHER, A., N. HOFER-INTEEWORN, C. KUMMERLEFRAUNE, N. M. FISCHER, C. FAVROT (2017): Triggers, risk factors and clinico-pathological features of urticaria in dogs - aprospective observational study of 24 cases. Vet. Dermatol. 28, 38-e39.

DOI:10.1111/vde.12342

ROUDEBUSH, P. ( 2013): Ingredients and foods associated with adverse reactions in dogs and cats. Vet. Dermatol. 24, 293-294.

DOI:10.1111/vde.12014

RUŽIČKA, R. (1990): Acupuncture in theory and practice NADAS, Praha, ČR, p. 9 (in Czech).

SCHOEN, A. M. (2001): Veterinary acupuncture: Ancient art to modern medicine. $2^{\text {nd }}$ ed., Elsevier - Health Sciences Division, St. Louis, USA, pp. 50-51, 289- 290.

STEINER, J. M. (2008): Small Animal Gastroenterology. Schlütersche Verlagsgesellschaft, Hannover, p. 253.

SVOBODA, M., J. DOUBEK, J. KONVALINOVÁ, A. NEČAS，J. RYBNÍČEK, V. SVOBODOVÁ (1994): Dermatology in dogs and cats. ČAVLMZ, Brno, ČR, pp. 240-254 (in Czech).
SWATI, K., A. DASGUPTA, A. MITRA (2011): Treatment efficacy of acupuncture, yoga and homeopathy in the indian context: A review. IJBSAHM 2, 1-20.

TSAI, K. S., Y. H. CHEN, H. Y. CHEN, E. Y. SHEN, Y. C. LEE, J. L. SHEN, S. Y. WU, J. G. LIN, Y. H. CHEN, W. C. CHEN (2014): Antipruritic effect of cold stimulation at the quchi acupoint (LI 11) in mice. BMC Complement. Altern. Med. 14, 341.

DOI: $10.1186 / 1472-6882-14-341$

VAN DEN BERG-WOLF, M., T. BURGOON (2017): Acupuncture and cutaneous medicine: Is it effective? Med. Acupunct. 29, 269-275.

DOI: $10.1089 /$ acu.2017.1227

VOLKMANN, M., J. M. STEINER, G. T. FOSGATE, J. ZENTEK, S. HARTMANN, B. KOHN (2017): Chronic diarrhea in dogs - retrospective study in 136 cases. J. Vet. Int. Med. 31, 1043-1055.

DOI: $10.1111 /$ jvim. 14739

WEIDINGER, G. (2015): Traditional Chinese Medicine. For patients and physicians. $6^{\text {th }}$ ed., Fontána, Olomouc, ČR, pp. 103-117 (in Czech).

WYNN, S. G., B. J. FOUGERE (2007): Veterinary Herbal Medicine. Materia Medica In Veterinary Herbal Medicine, Mosby Elsevier, St. Louis, Missouri, USA, pp. 599-603.

XIE, H., V. PREAST (2013): Traditional Chinese Veterinary Medicine. Fundamental Principles. $2^{\text {nd }}$ ed., Chi Institute Press, Reddick, Florida, USA, pp. 336-339.

Received: 5 February 2020

Accepted: 25 May 2020

MICHÁLOVÁ, A., M. FIALKOVIČOVÁ, Z. VRBANAC: Akupunktura u pasa s alergijom - prikaz slučaja. Vet. arhiv 91, 101-108, 2021.

\section{SAŽETAK}

Alergije su poremećaji imunosnog sustava koji uzrokuju reakcije na inače bezopasne tvari poznate kao alergeni, primjerice sastojci hrane, pelud, ubod insekata ili lijekovi. Zbog raznolikosti kliničkih znakova, za alergijska stanja iznimno je važno postaviti ispravnu dijagnozu kako bi se iz tijela uklonio alergen, te osigurala kontrola i ugodno životno okruženje životinje. U slučaju jakog svrbeža općenito se primjenjuju lijekovi poput glukokortikoida, antihistaminika i inhibitora Janus-kinaze. Nažalost uobičajeni lijekovi ne mogu uvijek riješiti svrbež uzrokovan alergijom. Ovaj prikaz slučaja opisuje alternativno liječenje, uključujući veterinarsku akupunkturu, dijetnu prehranu i fitoterapiju, koji su pokazali blagotvoran i ljekovit učinak u slučaju alergija.

Ključne riječi: alergija; tradicionalna kineska veterinarska medicina; akupunktura; dijetna prehrana; fitoterapija 